Metamorphosis in Craniiformea revisited Novocrania anomala shows delayed development of the ventral valve

Altenburger, Andreas; Wanninger, Andreas; Holmer, Lars E.

Published in:

Zoomorphology

DOI:

$10.1007 / \mathrm{s} 00435-013-0194-3$

Publication date:

2013

Document version

Early version, also known as pre-print

Citation for published version (APA):

Altenburger, A., Wanninger, A., \& Holmer, L. E. (2013). Metamorphosis in Craniiformea revisited: Novocrania anomala shows delayed development of the ventral valve. Zoomorphology, 132(4), 379-387. https://doi.org/10.1007/s00435-013-0194-3 


\title{
Metamorphosis in Craniiformea revisited - Novocrania anomala shows delayed development of the ventral valve
}

Running title: Metamorphosis in Novocrania

Andreas Altenburger, Andreas Wanninger, Lars E. Holmer

\section{Authors' names and addresses}

Andreas Altenburger, University of Copenhagen, Natural History Museum of Denmark - Zoological Museum, Universitetsparken 15, DK-2100 Copenhagen, Denmark, aaltenburger@snm.ku.dk, phone: +45 35321114

Andreas Wanninger, University of Vienna, Dept. of Integrative Zoology, Althanstr. 14, AUT-1090 Vienna, Austria

Lars E. Holmer, Uppsala University, Department of Earth Sciences, Palaeobiology, SE-752 36 Uppsala, Sweden

\begin{abstract}
We revisited the brachiopod fold hypothesis and investigated metamorphosis in the craniiform brachiopod Novocrania anomala. Larval development is lecithotrophic and the dorsal (brachial) valve is secreted by dorsal epithelia. We found that the juvenile ventral valve, which consists only of a thin layer that was previously described as periostracal, is not a valve, and is not secreted by the same epithelia as the dorsal valve. It is secreted by the attachment area of the larva at the posterior-most tip of the posterior larval lobe. The same attachment area is used by larvae of rhynchonelliform brachiopods during metamorphosis to cement their pedicle to the substrate. $N$. anomala is therefore not initially attached by a valve but by material
\end{abstract}


corresponding to pedicle cuticle. This is different to previous descriptions, which had led to speculations about a folding event in the evolution of Brachiopoda. We show that the "brachiopod fold hypothesis", which argues that brachiopods are transversely "folded" across the ontogenetic anterior-posterior axis, should be rejected at least with respect to the craniiforms. The data now suggest that the Craniiformea may be a derived group within the Rhynchonelliformea. This interpretation suggests that the last common ancestor of the Craniiformea has lost the pedicle and the ventral valve in early juvenile development. Characters that have previously been considered to be shared between the Craniiformea and the Linguliformea (clade Inarticulata), such as a through-gut and missing hinge articulation, may thus be secondarily derived characters of the Craniiformea within the Rhynchonelliformea.

\section{Keywords}

ontogeny, development, Craniiformea, phylogeny, morphology, body plan, evolution

\section{Introduction}

Brachiopoda is a marine animal phylum with a rich fossil record and approximately 370 recent species divided into the three clades, Craniiformea, Rhynchonelliformea, and Linguliformea (Williams et al. 1996; Zezina 2008). The evolution of the brachiopod body plan with two valves that enclose the soft tissue and a pedicle that attaches the animal to the substrate has puzzled researchers since the naming of the phylum by Duméril (1806). Brachiopods have since been deemed related to various phyla such as molluscs, bryozoans, annelids and recently, based on molecular data, to nemerteans (Grey 1848; Huxley 1853; Morse 1870; Dunn et al. 2008). 
Brachiopod internal relationships between the three clades, and the relation of brachiopods to phoronids, have not been completely resolved to date by molecular methods (Cohen et al. 1998; Cohen 2000; Cohen and Weydmann 2005; Sperling et al. 2011; Cohen 2013). Also, the comparative morphological analyses found an equal amount of characters shared among the Craniiformea and the Linguliformea (formerly the clade Inarticulata) and the Craniiformea and the Rhynchonelliformea (Carlson 1995). This has led to different outcomes in analyses concerning brachiopod internal phylogeny, depending on the chosen character polarities (Carlson 1995; Holmer et al. 1995; Williams et al. 1996). Characters shared among the craniiforms and the linguliforms include a through-gut, a circumferential mantle cavity, a muscular system consisting of oblique and two pairs of adductor muscles, as well as a transient median tentacle (Williams et al. 1996). Characters shared among the Craniiformea and the Rhynchonelliformea include a proteinaceaous calcitic shell, a single row of tentacles on trocholophous lophophores, gonads suspended in mantle sinuses, and lecithotrophic larvae (Holmer et al. 1995; Williams et al. 1996).

There are various hypotheses about the evolution of the brachiopod body plan. During the years, four hypotheses have been put forward. 1. The ancestor of brachiopods was a tube-dwelling polychaete-like metameric worm with a hydraulic body construction (Gutmann et al. 1978). 2. The ancestor of brachiopods was an oligomerous worm with setae, protocoel, mesocoel, and three segments in the metacoel (Temereva and Malakhov 2011). 3. The ancestor of brachiopods was a halkieriid-like organism, comprising a worm-like body with sclerites and shells at the anterior and posterior end (Conway Morris and Peel 1995; Cohen et al. 2003). 4. Brachiopods evolved from sclerite-bearing, tube-dewelling, worm-like organisms such as the tommotiids 
Micrina, Eccentrotheca, and Paterimitra (Williams and Holmer 2002; Holmer et al.

2008; Skovsted et al. 2009a; 2009b; Holmer et al. 2011; Murdock et al. 2012).

In living brachiopods, members of each clade have a distinct mode of development.

The larvae of Craniiformea are lecithotrophic, bilobed, with three pairs of dorsal setal bundles on the posterior lobe. The larvae of Rhynchonelliformea are lecithotrophic, have three lobes and four setal bundles at the mantle lobe, while the Linguliformea have planktotrophic, swimming juveniles (Nielsen 2005). Larvae of Craniiformea and Rhynchonelliformea metamorphose upon settlement. Swimming juveniles of Linguliformea do not undergo metamorphosis upon settlement because metamorphosis is mainly completed at the end of the embryonic stage in lingulids or shortly after hatching in the discinids (Lüter 2001, 2007; Popov et al. 2012). Hypotheses concerning the putative body plan of the ancestor of Brachiopoda often focus on the development of Novocrania anomala (Müller 1776) (previously assigned to several genera and therefore also referred to as Crania anomala or Neocrania anomala) (Lee and Brunton 1986, 2001), a member of the Craniiformea (Nielsen 1991; Popov et al. 1993; Conway Morris 1998; Cohen et al. 2003). It has been claimed that both valves in juveniles of $N$. anomala are secreted by mantle epithelia that originate at the dorsal side of the posterior lobe (Nielsen 1991). This notion has led to the conclusion that a "folding-event" happened during brachiopod evolution (Cohen et al. 2003; Malakhov and Kuzmina 2006). The concept was subsequently termed "brachiopod fold hypothesis", according to which brachiopods are assumed to transversely "fold" across the larval anterior-posterior axis. According to this theory, the brachiopod body plan needs to be conceptually "unfolded" in order to make useful comparisons with the body plans of other animal phyla (Cohen et al. 2003). The body plan of Halkieria evangelista as a possible stem group brachiopod was used to 
support this view (Conway Morris and Peel 1995; Cohen et al. 2003). However, the hypothesis that $H$. evangelista represents a brachiopod stem species has since been questioned (Vinther and Nielsen 2005).

The metamorphosis of $N$. anomala was described in detail with the claim that prior to metamorphosis 'most larvae become inactive and lie curled together on the bottom with the pair of ventral muscles maximally contracted' (Nielsen 1991). We tested whether these curled, inactive larvae are able to metamorphose by live observation, the use of F-actin labelling, confocal laser scanning microscopy, and scanning electron microscopy.

\section{Materials and Methods}

Collection of developmental stages

Adults of Novocrania anomala where obtained by dredging in the vicinity of the Sven Lovén Centre for Marine Sciences, Gullmarsfjord, Sweden (58¹5’921’N, $11^{\circ} 25^{\prime} 103$ 'E), in September 2008. The rocks with attached N. anomala were kept in running seawater at $14^{\circ} \mathrm{C}$. Adults were removed from the rocks and dissected. Eggs and sperm were removed with pulled glass pipettes, washed, and left in filtered seawater in separate beaker glasses. Fertilized eggs were regularly checked for germinal vesicle breakdown. Sperm cells were monitored for motility under a compound microscope. When eggs were ready for fertilization (approximately 12 hours after dissection), $2 \mathrm{ml}$ of a highly diluted sperm suspension were added. Embryos and larvae were fixed at various stages from 4 hours after fertilization (hpf) to 17 days after settlement in $4 \%$ paraformaldehyde in $0.1 \mathrm{M}$ phosphate buffer (PB) for $90 \mathrm{~min}$. Thereafter, larvae were washed three times for 15 min each in $0.1 \mathrm{M} \mathrm{PB}$ and finally stored in $0.1 \mathrm{M} \mathrm{PB}$ containing $0.1 \% \mathrm{NaN}_{3}$ at $4^{\circ} \mathrm{C}$. 


\begin{abstract}
Scanning electron microscopy
For scanning electron microscopy, the specimens were dehydrated in a graded ethanol and acetone series, critical point dried, sputter coated with gold, and investigated using a Zeiss Supra 35VP scanning electron microscope.
\end{abstract}

\title{
Confocal laserscanning microscopy
}

The musculature was stained with phalloidin. Prior to staining, fixed larvae were washed in phosphate buffer (PB) three times for 15 min each. Then, the larvae were incubated for $1 \mathrm{~h}$ in PB containing 0.2\% Triton X-100 (Sigma-Aldrich, St. Louis, MO, USA) to permeabilize the tissue, left overnight at $4^{\circ} \mathrm{C}$ in $0.1 \mathrm{M} \mathrm{PB}$ containing $0.2 \%$ Triton X-100 and 1:40 diluted Alexa Fluor 488 phalloidin (Invitrogen, Molecular Probes, Eugene, OR, USA), and subsequently washed in $0.1 \mathrm{M}$ PB that was changed three times every $15 \mathrm{~min}$. Finally, the specimens were embedded in Fluoromount G (Southern Biotech, Birmingham, AL, USA) on glass slides. Negative controls omitting the phalloidin dye were performed in order to test for autofluorescence and rendered no signal. The stained larvae and juveniles were analyzed with a Leica DM IRE2 fluorescence microscope equipped with a TCS SP2 AOBS laserscanning device (Leica Microsystems, Wetzlar, Germany). Animals were scanned with $0.16 \mu \mathrm{m}-0.49$ $\mu \mathrm{m}$ step size, and the resulting image stacks were merged into maximum projection images. Light micrographs were recorded to allow overlay with the CLSM images for exact orientation and localization of the muscle systems within the animals.

Schematic drawings and figure plates

Drawings and micrographs were assembled with Photoshop CS3 and Illustrator CS3 software (Adobe, San Jose, CA, USA). 


\section{Results}

Overview of larval development at $14^{\circ} \mathrm{C}$

Cleavage is radial and the first two divisions are holoblastic (Fig. 1A-B, 2A-B). The blastula is spherical (Fig. 2C) and invagination starts at around 18 hours after fertilization (hpf) (Fig. 2D). The blastocoel disappears completely at the gastrula stage (Fig. 1C). Subsequently, the gastrula elongates and the blastopore comes to lie at the postero-ventral side of the swimming larva (Fig. 1D, 2E). The elongated gastrula differentiates into two larval lobes, i.e., an anterior lobe and a posterior lobe (Fig. 1EF, 2F-G). Larval development is complete with the establishment of three pairs of dorsal setal bundles on the posterior lobe (Fig. 1G, 2H). Now the larvae are competent for metamorphosis and swim driven by the cilia that are around the anterior lobe. At this stage, the larvae have setae pouch muscles at the base of each bundle of setae. These setae pouch muscles are interconnected by medioventral longitudinal and transversal muscles (for a detailed description of myogenesis and larval myoanatomy of N. anomala see Altenburger and Wanninger, 2010).

Metamorphosis

At a water temperature of $14{ }^{\circ} \mathrm{C}$, metamorphosis takes place around six to ten days after fertilization (dpf). During metamorphosis the larva lies flat on the surface with the ventral side pointing towards the substrate. The anterior lobe and the posterior end of the posterior lobe are bent ventrally, thus exposing the dorsal posterior lobe to the environment (Fig. 4A-C). The larva attaches itself to the substrate with the posteriormost tip of the posterior lobe. The dorsal mantle develops from an oval-shaped area on the dorsal side of the posterior lobe and secretes the first-formed brachial valve 
(Fig. 4D-F, 3B). The larval lobes are retained during the first steps of metamorphosis and are subsequently remodeled to form the lophophore and other adult organs (Figs. $1 \mathrm{H}, 2 \mathrm{I})$.

Prior to settlement, the larva swims along the bottom of the culture dish, probably in order to test if the substrate is suitable for settlement. Larvae ready for metamorphosis appear to be slightly curled, as they turn the anterior lobe and the posterior tip of the posterior lobe ventrally. However, strongly curled larvae with maximally contracted musculature are arrested in their development and unable to metamorphose (Fig. 3A, 3D). The larval musculature of healthy, settling, and metamorphosing individuals remains elongated and relaxed (i.e., non-contracted) prior its resorption in the juvenile (Fig. 3E). There is no ventral mantle at this stage of development (Fig. 2I, 3C). Some days after settlement the larval lobes give rise to the adult tissues including the lophophore (Fig. 3F).

\section{Discussion}

Development and regional specification during Novocrania anomala embryogenesis were described previously, but interpreted differently (Nielsen 1991; Freeman 2000). According to all observations (published previously and presented herein) the cilia on the anterior lobe function as locomotory organ of the larva prior to metamorphosis. Once the larva has found a suitable place for settlement it attaches itself to the substrate with the posterior-most tip of the posterior lobe, which is bent ventrally. A distinguishable domain of cells between the setal bundles on the dorsal side of the posterior lobe participates in the formation of the mantle that will secrete the dorsal valve during metamorphosis (Fig. 4 D-E) (Nielsen 1991; Freeman 2000). Nielsen (1991, page 25) states moreover: “...the brachial ('dorsal’) valve was secreted by the 
anterior part of the dorsal side of the larva while the pedicle ('ventral') valve was secreted by the posterior part of the dorsal side, i. e. both valves are actually dorsal!". We reject this interpretation for several reasons. First of all, the attachment area of the larvae is the posterior-most tip of the posterior lobe, thus one cannot make a distinction between dorsal or ventral at this point. It is further not clear which epithelia form the ventral mantle that would be needed to secrete the ventral valve. It was assumed that the ventral valve is secreted by and spreads from the attachment area (Nielsen 1991). We agree with the assumption that cuticle spreads from the attachment area. However, we disagree that it is a valve, as the juveniles in our experiments did not develop a ventral mantle that could secrete the ventral valve within the first 17 days after metamorphosis. This is seen in the specimen shown in Fig. 4 D-F, which has a mantle on the dorsal side of the larva but not on the ventral side. The juvenile specimens in Fig. 2I and 3C, which are shown from the ventral side, likewise have a dorsal valve but neither a ventral valve nor a ventral mantle. Only the attachment area is visible at this stage of development, which makes it clear that the absence of a ventral mantle and a ventral valve is not due to experimental procedures.

The development of the ventral valve in post-metamorphic stages of N. anomala is delayed. A similar delay of ventral valve development is found in juvenile stages of the Ordovician craniid Orthisocrania and in some palaeozoic rhynchonelliforms such as Antigonambonites (Popov et al. 2007; Popov et al. 2010). Later stages of $N$. anomala show a ventral valve consisting of a very thin periostracal layer with which the animals cement themselves to the substrate (Rowell 1960). According to these observations, the ventral mantle does not begin to secrete calcite until the animals are in the "12 - 14 pairs of cirri stage" and about $1 \mathrm{~mm}$ wide (Rowell 1960). 
Generally, the ventral valve of adult $N$. anomala show "a predominantly organic layer and Wright 1970, page 48). In mature adults, over $10 \mathrm{~mm}$ in diameter, a calcitic thickening exceeding $0.5 \mathrm{~mm}$ is limited to an anterior arc which forms a dorsally convex submarginal rim so that a central area, between 3 and $5 \mathrm{~mm}$ across, remains only partially covered by the merest mineral film (Williams and Wright 1970). It is well established that the Craniida occur in the fossil record not before the Lower Ordovician with the clade Pseudocrania (Bassett 2000). This is late compared to the Linguliformea and the Rhynchonelliformea which are found much earlier in the fossil record, namely already in the Lower Cambrian (Williams et al. 2007). Many phylogenetic analyses hint towards the Craniiformea as being derived within Brachiopoda, based on both morphological and molecular data (Carlson 1995; Holmer et al. 1995; Cohen 2000; Cohen and Weydmann 2005). It thus makes no sense to hypothesize a potential body plan ground pattern based on the development of $N$. anomala, because of the risk to take an apomorphy of a subclade as a character for the whole taxon (Wägele 2005).

The attachment area of $N$. anomala is at the posterior-most tip of the posterior lobe (Nielsen 1991). Also the lecithotrophic larvae of rhynchonelliform brachiopods attach themselves with the posterior-most tip of their pedicle lobe to the substrate at the onset of metamorphosis (Altenburger and Wanninger 2009). This pedicle lobe contains the primordium of the juvenile pedicle that forms after metamorphosis (Stricker and Reed 1985a). In the rhynchonelliform larva the dorsal and ventral valves are secreted by mantle epithelium that is formed on the underside of the skirt-like mantle lobe, which is reverted over the apical lobe during metamorphosis (Stricker and Reed $1985 b, c)$. In $N$. anomala no inversion takes place. Here, the dorsal valve is 
secreted from the dorsal mantle after settlement, and there is no ventral valve at this

stage. In our view the cementing cuticle of $N$. anomala may represent the same material that is used to attach the pedicle to the substrate in rhynchonelliform brachiopods. Rhynchonelliform brachiopods glue themselves to the substrate by a sticky secretion for tentative attachment, followed by secretion of a layer of cuticle which is secreted between the glued pedicle and substrate for permanent attachment (Stricker and Reed 1985a; Chuang 1996). From this perspective, the lecithotrophic larvae of Rhynchonelliformea and Craniiformea are not that different. Because, if one takes the skirt-like mantle that constitutes the mantle lobe of three-lobed rhynchonelliform larvae away, and consequently the ability to invert the skirt-like lobe over the apical lobe during metamorphosis, the remaining larva is bilobed. The body plan of $N$. anomala could resemble an early stage rhynchonelliform larva before it separates the mantle from the pedicle lobe. In the rhynchonelliform Terebratalia transversa (Sowerby, 1846), the mantle lobe forms during a second constriction as an outgrowth from the pedicle lobe from the dorsal side of the larva and slowly grows around both sides of the larva towards the ventral side (Stricker and Reed 1985b; Freeman 2003). Larva of $N$. anomala might keep the prospective mantle cells, which later also develop the setal sacs on their dorsal side, without developing a mantle lobe. These considerations lead us to the conclusion that Craniiformea might be a derived group within Rhynchonelliformea that has lost the pedicle and the ventral valve in early postmetamorphic development. This view is supported by the following characters uniting the craniiforms and the rhynchonelliforms: 1. Lecithotrophic larvae with an attachment area at the posterior-most tip of the larva. 2. Calcitic shells with punctae (Williams 1997). 3. The gonads are placed within the mantle canals (Popov et al. 1993). 4. One pair of oblique muscles is present (Popov et al. 1993). 
The following characters have previously been used to unite the Craniiformea with

the Linguliformea (to form the clade Inarticulata), but these may more likely represent apomorphies of the Craniiformea within the Rhynchonelliformea: a secondary through-gut at the posterior body wall, and loss of hinge articulation because of loss of the ventral valve in early postmetamorphic development. The craniiform body plan is thus derived from the rhynchonelliform body plan and the Craniiformea may represent a subclade of the Rhynchonelliformea. A naming of this clade has already been proposed as the Calciata (Popov et al. 1993).

Our observations contribute significantly to the understanding of brachiopod interrelationships which are still hotly debated, especially with regard to the position of Phoronida (Helmkampf et al. 2008; Sperling et al. 2011; Cohen 2013; Cohen and Bitner 2013). In relation to our findings this is relevant because in a study based on nuclear housekeeping genes combined with three ribosomal genes, the craniids behave as a "rogue taxon" that is placed with little statistical resolution at the base of Brachiopoda (Sperling et al. 2011).

Coming back to the metamorphosis of $N$. anomala we want to point out a further important difference to the previously described mechanisms. This concerns the ability of maximally contracted curled larvae to metamorphose. Although we observed curled larvae, these are arrested in development and do not metamorphose. While curled larvae have contracted muscles (Fig. 3D), all individuals that successfully completed metamorphosis in our study $(\mathrm{N}=15)$ showed relaxed, i.e., expanded medioventral longitudinal muscles after settlement and prior to resorption (Fig. 3E; see also Altenburger and Wanninger 2010 for a general description of the musculature in N. anomala). Also the anterior-posterior alignment of the gut of the adults is incompatible with a "folding" event of the body axis during metamorphosis 
(Williams and Carlson 2007). Another argument is the presence of complete ventral and dorsal mesenteries in N. anomala (Chuang 1960). Phoronids, which are 'folded' animals, have developed lateral mesenteries instead (Bailey-Brock and Emig 2000). Especially the hypothesis of a "brachiopod fold" put forward by Cohen et al. (2003) focuses on the "curling" event prior to metamorphosis. However, if one wants to make this comparison, the "fold" would be between the anterior and the posterior lobe of the larva. To arrive at a brachiopod body plan from this folding event, one valve had to be secreted from the dorsal anterior lobe and the other one from the dorsal posterior lobe. But this is not the case and it was never reported that way. Accordingly, the larvae do neither fold before nor during metamorphosis, they only bend the anterior lobe and the posterior-most tip of the posterior lobe ventrally. Thus, hypotheses arguing for a "brachiopod fold event" during brachiopod evolution are not supported by larval development and metamorphosis of N. anomala and should therefore be rejected.

\section{Acknowledgements}

We thank Andreas Schmidt-Rhaesa for helpful comments that significantly improved the manuscript. We are grateful to the staff at the Sven Lovén Centre for Marine Sciences in Kristineberg, Sweden, for providing laboratory space. Gary Wife (University of Uppsala) is thanked for assistance with the scanning electron microscope. Lars Holmer acknowledges support from the Swedish Research Council (VR 2009-4395, 2012-1658). 


\section{References}

Altenburger A, Wanninger A (2009) Comparative larval myogenesis and adult myoanatomy of the rhynchonelliform (articulate) brachiopods Argyrotheca cordata, A. cistellula, and Terebratalia transversa. Front Zool 6:3. doi:10.1186/1742-9994-6-3

Altenburger A, Wanninger A (2010) Neuromuscular development in Novocrania anomala: evidence for the presence of serotonin and a spiralian-like apical organ in lecithotrophic brachiopod larvae. Evol Dev 12:16-24. doi:10.1111/j.1525-142X.2009.00387.x

Bailey-Brock JH, Emig CC (2000) Hawaiian Phoronida (Lophophorata) and Their Distribution in the Pacific Region. Pac Sci 54:119-126

Bassett MG (2000) Craniida. In: Kaesler RL (ed) Treatise on Invertebrate Paleontology, Part H, Brachiopoda, Revised, vol 2. The Geological Society of America Inc. and The University of Kansas, pp 169-183

Carlson SJ (1995) Phylogenetic relationships among extant brachiopods. Cladistics 11:131-197. doi:10.1016/0748-3007(95)90010-1

Chuang SH (1960) An anatomical, histological, and histochemical study of the gut of the brachiopod, Crania anomala. Q J Microsc Sci 101:9-18 
Chuang SH (1996) Competence, pre- and post-settlement choices of articulate brachiopod larvae. In: Copper P, Jin J (eds) Brachiopods: Proceedings of the third International Brachiopod Congress. A.A. Balkema, Rotterdam, pp 65-67

Cohen BL (2000) Monophyly of brachiopods and phoronids: reconciliation of molecular evidence with Linnaean classification (the subphylum Phoroniformea nov.). Proc R Soc B 267:225-231. doi:10.1098/rspb.2000.0991

Cohen BL (2013) Rerooting the rDNA gene tree reveals phoronids to be 'brachiopods without shells'; dangers of wide taxon samples in metazoan phylogenetics (Phoronida; Brachiopoda). Zool J Linn Soc 167:82-92. doi:10.1111/j.10963642.2012.00869.x

Cohen BL, Bitner MA (2013) Molecular phylogeny of rhynchonellide articulate brachiopods (Brachiopoda, Rhynchonellida). J Paleontol 87:211-216. doi:10.5061/Dryad.79411

Cohen BL, Gawthrop A, Cavalier-Smith T (1998) Molecular phylogeny of brachiopods and phoronids based on nuclear-encoded small subunit ribosomal RNA gene sequences. Philos T R Soc B 353:2039-2061. doi:10.1098/rstb.1998.0351

Cohen BL, Holmer LE, Lüter C (2003) The brachiopod fold: A neglected body plan hypothesis. Palaeontology 46:59-65. doi:10.1111/1475-4983.00287 
Cohen BL, Weydmann A (2005) Molecular evidence that phoronids are a subtaxon of brachiopods (Brachiopoda: Phoronata) and that genetic divergence of metazoan phyla began long before the early Cambrian. Org Divers Evol 5:253-273. doi:10.1016/j.ode.2004.12.002

Conway Morris S (1998) The crucible of creation: the Burgess Shale and the rise of animals. Oxford University Press, Oxford

Conway Morris S, Peel JS (1995) Articulated halkieriids from the Lower Cambrian of North Greenland and their role in early protostome evolution. Philos Trans R Soc Lond B Biol Sci 347:305-358. doi:10.1098/rstb.1995.0029

Duméril C (1806) Zoologie analytique, ou Méthode naturelle de classification des animaux. Allais, Paris. doi:10.5962/bhl.title.11646

Dunn CW, Hejnol A, Matus DQ, Pang K, Browne WE, Smith SA, Seaver E, Rouse GW, Obst M, Edgecombe GD, Sorensen MV, Haddock SH, Schmidt-Rhaesa A, Okusu A, Kristensen RM, Wheeler WC, Martindale MQ, Giribet G (2008) Broad phylogenomic sampling improves resolution of the animal tree of life. Nature 452:745-749. doi:10.1038/nature06614

Freeman G (2000) Regional specification during embryogenesis in the craniiform brachiopod Crania anomala. Dev Biol 227:219-238. doi:10.1006/dbio.2000.9857 
Freeman G (2003) Regional specification during embryogenesis in Rhynchonelliform brachiopods. Dev Biol 261:268-287

Grey JE (1848) On the arrangement of the Brachiopoda. Ann Mag nat Hist 2:435-440

Gutmann WF, Vogel K, Zorn H (1978) Brachiopods - biomechanical interdependences governing their origin and phylogeny. Science 199:890-893. doi:10.1126/science.199.4331.890

Helmkampf M, Bruchhaus I, Hausdorf B (2008) Phylogenomic analyses of lophophorates (brachiopods, phoronids and bryozoans) confirm the Lophotrochozoa concept. Proc R Soc B 275:1927-1933. doi:10.1098/rspb.2008.0372

Holmer LE, Popov LE, Bassett MG, Laurie J (1995) Phylogenetic analysis and ordinal classification of the Brachiopoda. Palaeontology 38:713-741

Holmer LE, Skovsted CB, Brock GA, Valentine JL, Paterson JR (2008) The Early Cambrian tommotiid Micrina, a sessile bivalved stem group brachiopod. Biol Lett 4:724-728. doi:10.1098/rsbl.2008.0277

Holmer LE, Skovsted CB, Larsson C, Brock GA, Zhang Z (2011) First record of a bivalved larval shell in Early Cambrian tommotiids and its phylogenetic significance. Palaeontology:235-239. doi:10.1111/j.1475-4983.2010.01030.x 
Huxley TH (1853) On the morphology of the cephalous mollusca, as illustrated by the anatomy of certain Heteropoda and Pteropoda collected during the voyage of H.M.S. "Rattlesnake" in 1846-50. Phil Trans R Soc Lond 143:29-65. doi:10.1098/rstl.1853.0002

Lee DE, Brunton CHC (1986) Neocrania n. gen., and a revision of Cretaceous-Recent brachiopod genera in the family Craniidae. Bull Br Mus (Nat Hist) Geol 40:141-160

Lee DE, Brunton CHC (2001) Novocrania, a new name for the genus Neocrania Lee \& Brunton, 1986 (Brachiopoda, Craniida), preoccupied by Neocrania Davis, 1978 (Insecta, Lepidoptera). Bull nat Hist Mus Lond (Geol) 57:5

Lüter C (2001) Brachiopod larval setae - a key to the phylum's ancestral life cycle? In: Brunton CHC, Cocks LRM, Long SL (eds) Brachiopods Past and Present, vol 63. Systematics Association Special Volumes. CRC Press, pp 46-55

Lüter C (2007) Anatomy. In: Selden PA (ed) Treatise on Invertebrate Paleontology, Part H, Brachiopoda, Revised, vol 6. The Geological Society of America, Inc. and The University of Kansas, Boulder, Colorado, and Lawrence, Kansas, pp 2321-2355

Malakhov VV, Kuzmina TV (2006) Metameric origin of lateral mesenteries in Brachiopoda. Dokl Biol Sci 409:340-342. doi:10.1134/s0012496606040223 
Murdock DJE, Donoghue PCJ, Bengtson S, Marone F (2012) Ontogeny and microstructure of the enigmatic Cambrian tommotiid Sunnaginia Missarzhevsky, 1969. Palaeontology 55:661-676. doi:10.1111/j.14754983.2012.01131.x

Nielsen C (1991) The development of the brachiopod Crania (Neocrania) anomala (O. F. Müller) and its phylogenetic significance. Acta Zool 72:7-28. doi:10.1111/j.1463-6395.1991.tb00312.x

Nielsen C (2005) Trochophora larvae: cell-lineages, ciliary bands and body regions. 2. Other groups and general discussion. J Exp Zool Part B Mol Dev Evol 304:401-447. doi:10.1002/jez.b.21050

Popov LE, Bassett MG, Holmer LE (2012) Earliest ontogeny of Early Palaeozoic Craniiformea: compelling evidence for lecithotrophy. Lethaia 45:566-573. doi:10.1111/j.1502-3931.2012.00315.x

Popov LE, Bassett MG, Holmer LE, Laurie J (1993) Phylogenetic analysis of higher taxa of Brachiopoda. Lethaia 26:1-5. doi:10.1111/j.1502-3931.1993.tb01502.x

Popov LE, Bassett MG, Holmer LE, Skovsted CB, Zuykov MA (2010) Earliest ontogeny of Early Palaeozoic Craniiformea: implications for brachiopod phylogeny. Lethaia 43:323-333. doi:10.1111/j.1502-3931.2009.00197.x

Popov LE, Egerquist E, Holmer LE (2007) Earliest ontogeny of Middle Ordovician rhynchonelliform brachiopods (Clitambonitoidea and Polytoechioidea): 
implications for brachiopod phylogeny. Lethaia 40:85-96. doi:10.1111/j.15023931.2006.00008.x

\author{
Rowell AJ (1960) Some early stages in the development of the brachiopod Crania \\ anomala (Müller). Annals and Magazine of Natural History 13:35-56
}
Skovsted CB, Balthasar U, Brock GA, Paterson JR (2009a) The tommotiid Camenella reticulosa from the early Cambrian of South Australia: Morphology, scleritome reconstruction, and phylogeny. Acta Palaeontol Pol 54:525-540. doi:10.4202/app.2008.0082
Skovsted CB, Holmer LE, Larsson CM, Högström AES, Brock GA, Topper TP, Balthasar U, Stolk SP, Paterson JR (2009b) The scleritome of Paterimitra: an Early Cambrian stem group brachiopod from South Australia. Proc R Soc B 276:1651-1656. doi:10.1098/rspb.2008.1655

Sperling EA, Pisani D, Peterson KJ (2011) Molecular paleobiological insights into the origin of the Brachiopoda. Evol Dev 13:290-303. doi:10.1111/j.1525142X.2011.00480.x

\author{
Stricker SA, Reed CG (1985a) Development of the pedicle in the articulate \\ brachiopod Terebratalia transversa (Brachiopoda, Terebratulida). \\ Zoomorphology 105:253-264. doi:10.1007/BF00311968
}


Stricker SA, Reed CG (1985b) The ontogeny of shell secretion in Terebratalia transversa (Brachiopoda, Articulata). 1. Development of the mantle. J Morphol 183:233-250. doi:10.1002/jmor.1051830302

Stricker SA, Reed CG (1985c) The ontogeny of shell secretion in Terebratalia transversa (Brachiopoda, Articulata). 2. Formation of the protegulum and juvenile shell. J Morphol 183:251-271. doi:10.1002/jmor.1051830303

Temereva EN, Malakhov VV (2011) The evidence of metamery in adult brachiopods and phoronids. Invert Zool 8:87-101

Vinther J, Nielsen C (2005) The Early Cambrian Halkieria is a mollusc. Zool Scr 34:81-89. doi:10.1111/j.1463-6409.2005.00177.x

Williams A (1997) Shell structure. In: Kaesler RL (ed) Treatise on Invertebrate Paleontology. Part H. Brachiopoda (Revised), vol. 1. The Geological Society of America \& Paleontological Institute, Boulder, Colorado \& Lawrence, Kansas, pp 267-320

Williams A, Carlson SJ (2007) Affinities of brachiopods and trends in their evolution. In: Selden PA (ed) Treatise on Invertebrate Paleontology, Part H, Brachiopoda, Revised, vol 6. Geological Society of America \& Paleontological Institute, Boulder, Colorado \& Lawrence, Kansas,

Williams A, Carlson SJ, Brunton CHC (2007) Outline of suprafamilial classification and authorship. In: Selden PA (ed) Treatise on Invertebrate Palaeontology. 
Part H. Brachiopoda (revised), vol 6. The Geological Society of America and The University of Kansas, Boulder, Colorado and Lawrence, Kansas, pp XXXIX-XLV

Williams A, Carlson SJ, Brunton CHC, Holmer LE, Popov L (1996) A supra-ordinal classification of the Brachiopoda. Proc R Soc B 351:1171-1193. doi:10.1098/rstb.1996.0101

Williams A, Holmer LE (2002) Shell structure and inferred growth, functions and affinities of the sclerites of the problematic Micrina. Palaeontology 45:845873. doi:10.1111/1475-4983.00264

Williams A, Wright AD (1970) Shell Structure of the Craniacea and other calcareous inarticulate Brachiopoda. Spec Pap Palaeontol:1-51

Wägele J-W (2005) Foundations of Phylogenetic Systematics. Verlag Dr. Friedrich Pfeil, München

Zezina O (2008) Biogeography of the recent brachiopods. Paleontol J 42:830-858. doi:10.1134/s0031030108080078 


\section{Figures}

Fig. 1. Sketch drawings of developmental stages of Novocrania anomala. Numbers indicate the age in hours after fertilization for all stages at $14^{\circ} \mathrm{C}$, except for $\mathrm{H}$ where it represents hours after the onset of metamorphosis. Size of all stages is around $130 \mu \mathrm{m}$ in diameter. Anterior is oriented upwards. Cilia were omitted for clarity. A, Unfertilized oocyte (black) with fertilization membrane (grey). B, Apical view of a four cell stage with the egg shell and two polar bodies (small circles). C, Frontal view of a gastrula with blastopore (asterisk), ectoderm (ec), and endoderm (en). The gastrula starts to swim at this stage. D, Lateral view of an elongated gastrula with ectoderm (ec) and endoderm (en). The blastopore (asterisk) is situated at the posterior pole of the gastrula. E, Dorsal view of an elongated gastrula with anterior lobe (AL). F, Ventral view of an early two-lobed larva with anterior lobe (AL) and posterior lobe (PL). The blastopore is closed at this stage. Larval setae pouch muscles (red circles) start to develop, and larval setae (se) have started to grow on the posterior side. G, Dorsal view of a fully developed larva with anterior lobe (AL), posterior lobe (PL), and three pairs of dorsal setal bundles (se) that are moved by fully developed setae pouch muscles (red circles). The setae pouch muscles are ventrally interconnected by two strands of medioventral longitudinal muscles (red longitudinal bars). The medioventral longitudinal muscles are interconnected by three bundles of transversal muscles (red transversal bars). See also Fig. 1 in Altenburger and Wanninger 2010 for the original data on myoanatomy. $\mathrm{H}$, Ventral view of a juvenile after metamorphosis. The larval anterior lobe (AL) and posterior lobe (PL) are still visible. The juvenile valve (v) is formed on the dorsal side with larval setae (se) extending from it. The larval setae are pushed outwards by the juvenile valve and the larval musculature is resorpt. 
Fig. 2. Scanning electron micrographs of Novocrania anomala developmental stages. Anterior is oriented upwards, scale bars equal $25 \mu \mathrm{m}$, numbers in the upper right corner of each specimen indicate the developmental time in hours after fertilization (A-H) or hours after settlement (I) at $14^{\circ} \mathrm{C}$. A, Four cell stage. B, Eight cell stage with polar bodies and radial cleavage pattern. C, Coeloblastula stage. D, Lateral view of a spherical gastrula with blastopore (arrowhead). E, Ventral view of a wedge-shaped gastrula with blastopore (arrowhead). F, Ventral view of a wedge-shaped gastrula with first anlage of the anterior lobe (AL) and almost closed blastopore (arrowhead). G, Dorsolateral view of an early larva with anterior lobe (AL) and posterior lobe (PL). Three sets of larval setal bundles (se) start to grow on the dorsal side of the posterior lobe. $\mathrm{H}$, Ventral view of a fully developed larva with anterior lobe (AL), posterior lobe (PL), and three pairs of setal bundles (se). I, Ventral view of a settled juvenile with dorsal valve (v) seen from ventral, anterior lobe (AL), posterior lobe (PL), and the attachment area on the substrate (arrow).

Fig. 3. The musculature in larvae of Novocrania anomala prior to and after metamorphosis. Anterior is up in all micrographs and scale bars equal $25 \mu \mathrm{m}$. A-C, scanning electron micrographs. A, Dorsolateral view of a folded larva as described by Nielsen (1991) with anterior lobe (AL), posterior lobe (PL), and three pairs of setal bundles (se). This folded larva is not able to metamorphose. B, Dorsal view of a settled juvenile with dorsal valve (v) and remaining larval setae (se). C, Ventral view of a settled juvenile with dorsal valve (v), anterior lobe (AL), posterior lobe (PL), and attachment area on the posterior lobe (arrow). D-E, Confocal micrographs of a larva (D) and a juvenile (E), corresponding to the stages shown in A and B. Muscles appear 
red in the micrographs. D, Ventrolateral view of a folded larva corresponding to the stage shown in A with anterior lobe (AL), posterior lobe (PL), and strongly contracted musculature (empty arrow). In healthy specimens, the larval musculature is elongated between anterior and posterior lobe. E, Ventral view of a settled juvenile with dorsal valve (v) and elongated larval longitudinal musculature (empty arrows). The larval lobes, i.e., the anterior lobe (AL) and the posterior lobe (PL), are still recognizable under the valve. F, Light micrograph of a settled juvenile with remaining larval setae (se), dorsal valve (v), anterior lobe that is remodeled to form the lophophore (AL/Lo), and remnants of the posterior lobe (PL).

Fig. 4. Larvae of Novocrania anomala during metamorphosis. A-C, early stage just after settlement seen from dorsolateral (A), lateral (B), and ventrolateral (C) with first-formed coat (c) on the dorsal posterior lobe, three pairs of dorsal setal bundles (se), anterior lobe (AL), and posterior lobe (PL). The first-formed coat (c) is the first material that is simultaneously secreted by the epithelial cells situated on the dorsal side of the posterior lobe. D-F, Later stage seen from dorsolateral (D), lateral (E), and ventral (F) with one pair of anterior setae bundles (se), first-formed valve (fv), dorsal mantle (m), anterior lobe (AL), and posterior lobe (PL). Note that the posterior setae bundles have been shed at this stage and the left part of the ventral side in F was slightly damaged during preparation of the specimen. 

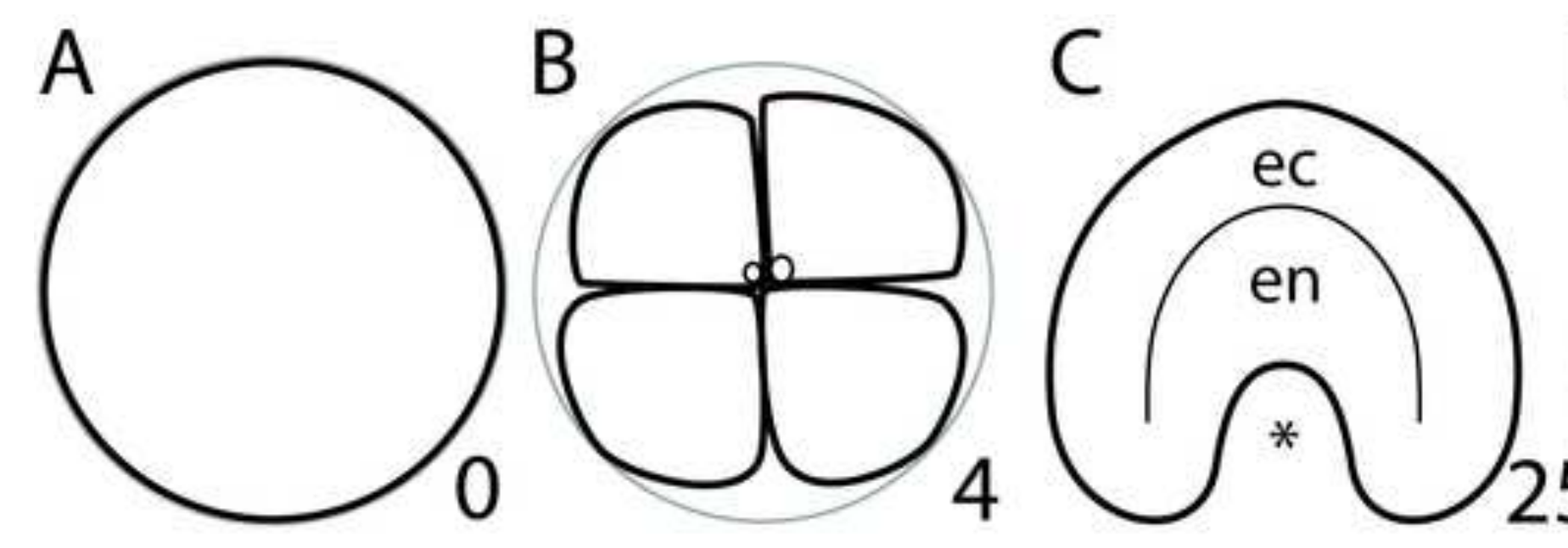

D

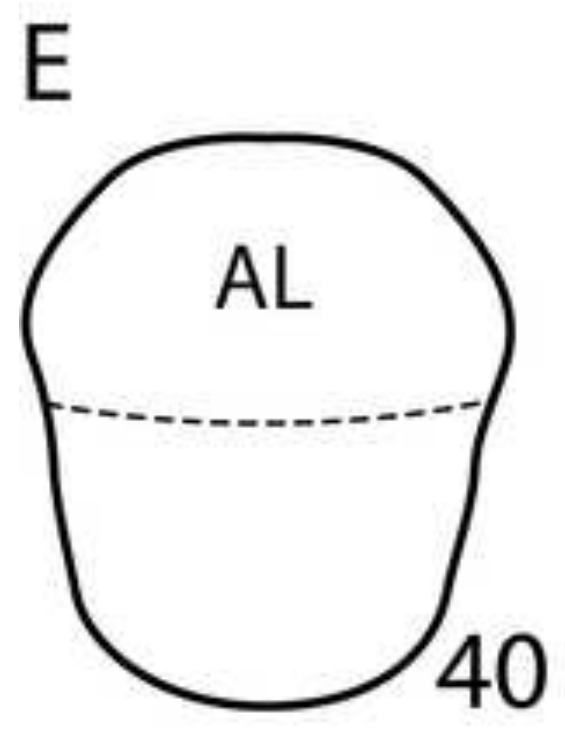

$F$

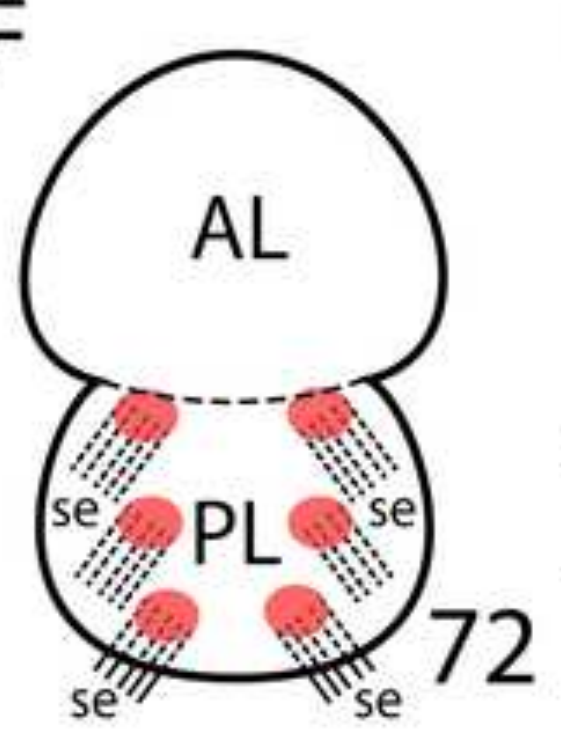

$G$
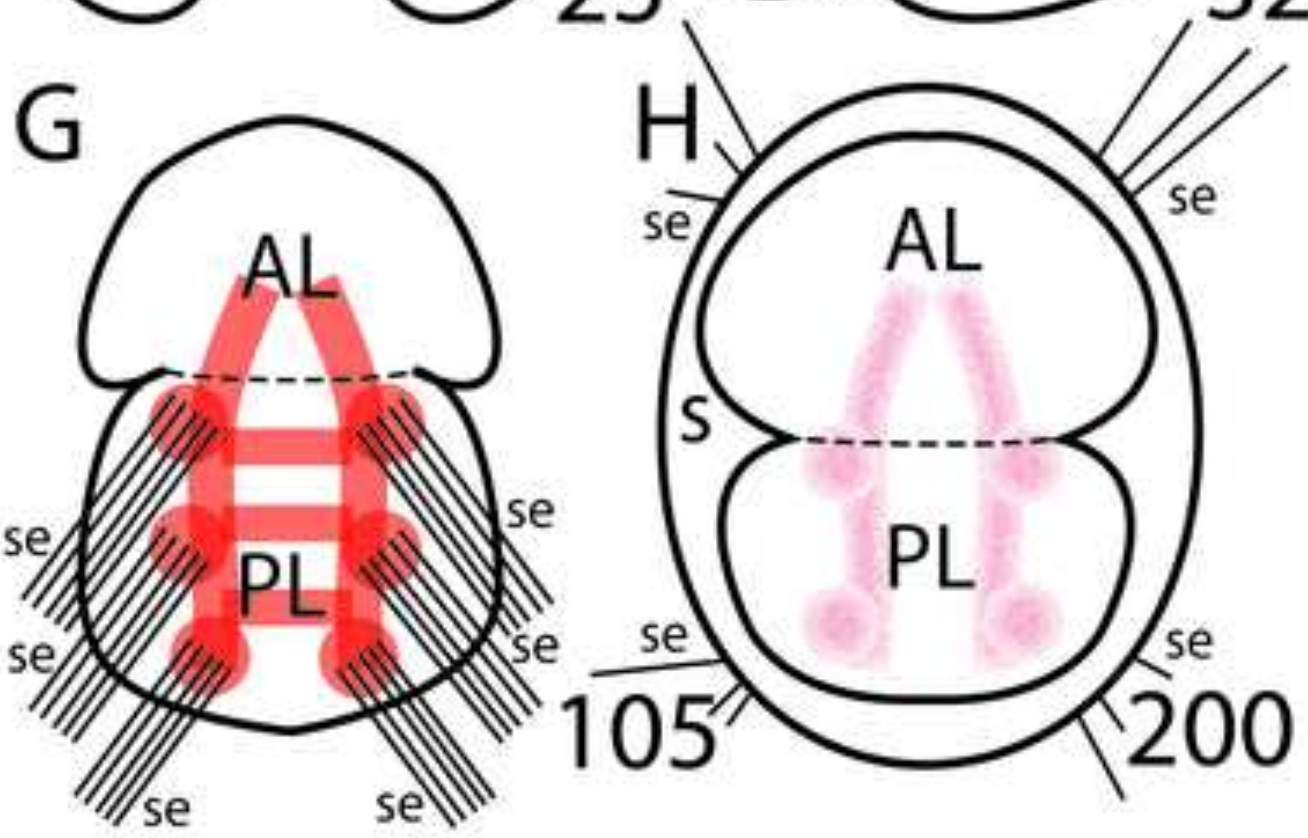

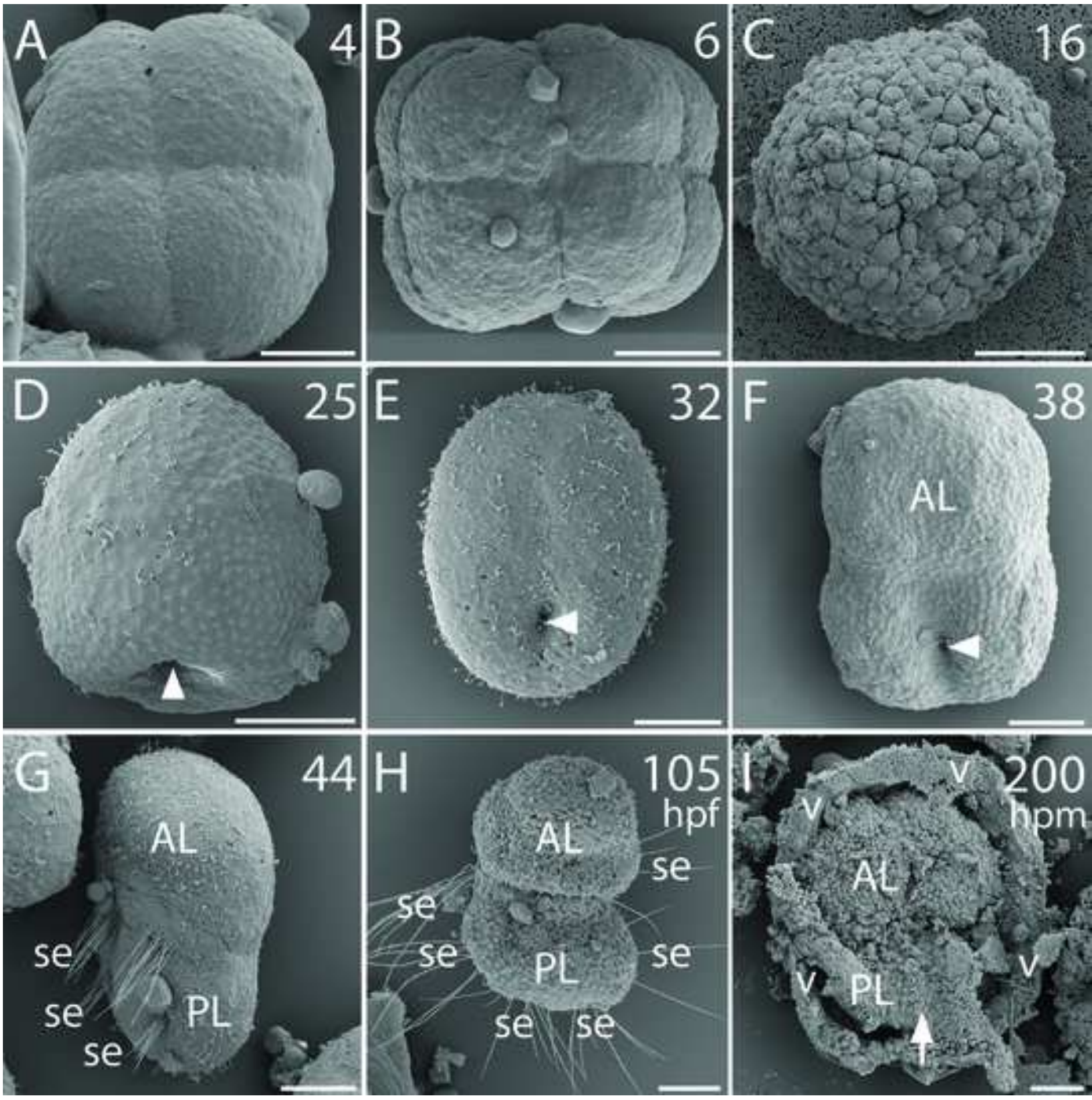

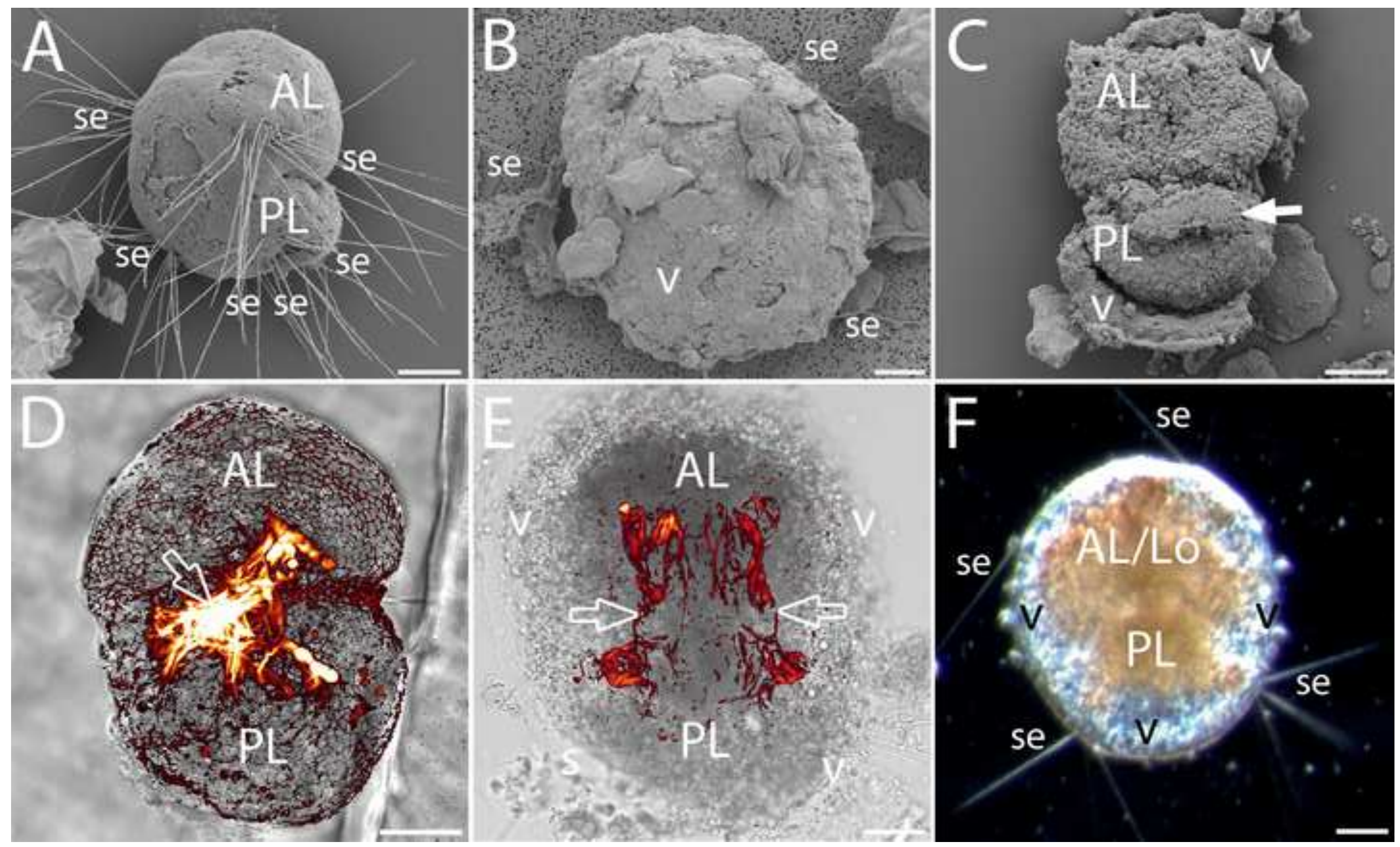


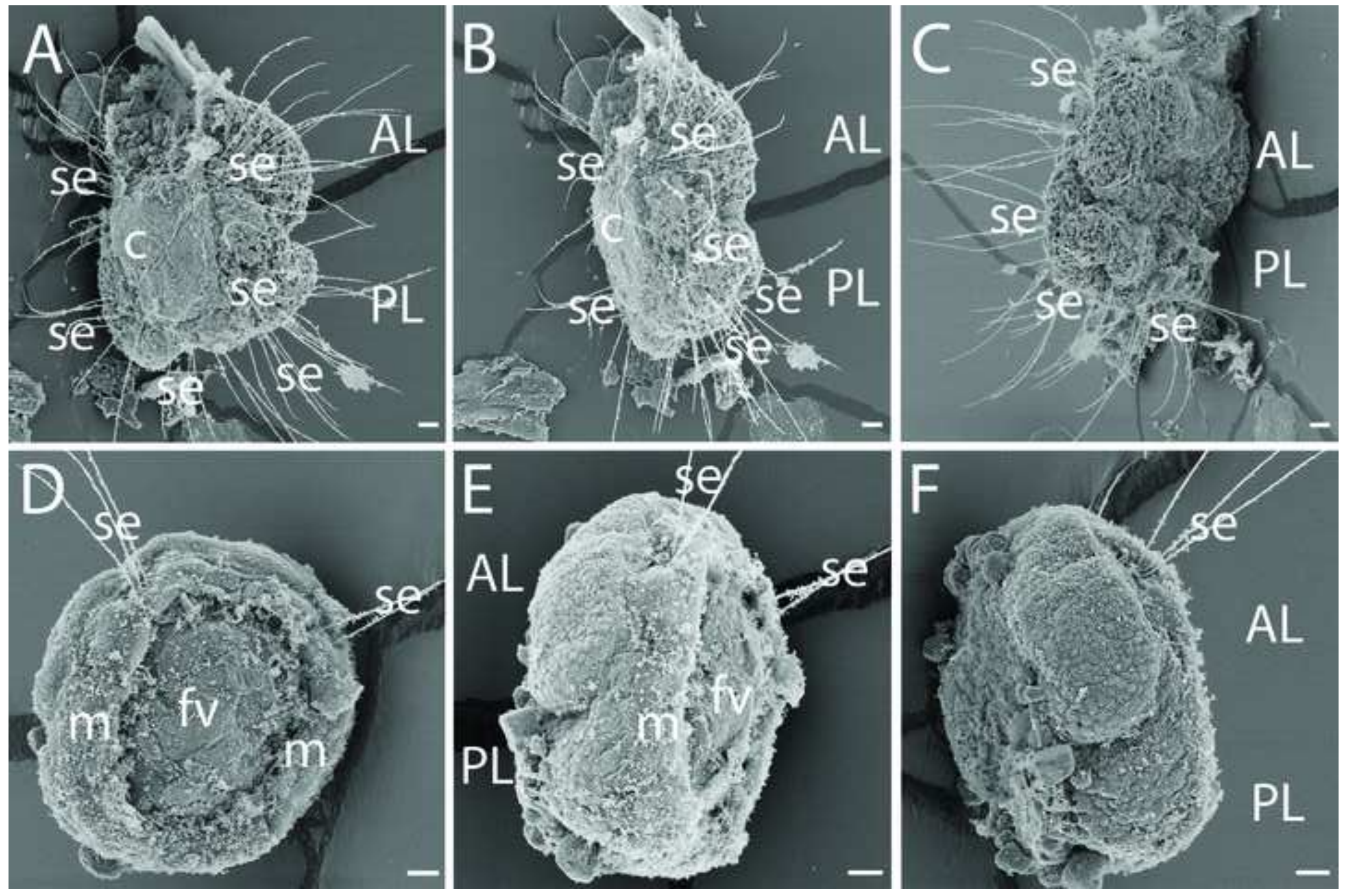

